\title{
AN INTERNATIONAL CONFERENCE ON PEACE EDUCATION: WHAT SCHOOLS CAN CONTRIBUTE ${ }^{1}$
}

WAZIR $A L I^{2}$

The welcome address by the president of the Turkish-German Education Foundation and by the mayor of Mannheim highlighted the fact that schools can play a better role in peace education in divided societies. The language of the conference was German but translation into English and Turkish was available.

According to the conference website, peace education should highlight all the patterns and structures that stimulate violence at an early stage and transform them into conflict-solving behaviour. In other words, the main purpose of the conference was to identify and analyse what factors actually play an important role in peace education, and to visualise how teachers and parents could contribute to promoting values and different behaviors that might be relevant to peace education. In addition to these elements, the increasing level of cultural diversity at schools as a resource for social development and peacekeeping is and will remain a challenge to integrating societies in different parts of the world. The main reason for organizing this type of conference was therefore to see how the experts who are involved typically locally or internationally-renowned academics and politicians - see and understand the paradigm of peace education. The conference lasted twodays and was attended by about two hundred participants from across the world including students, school teachers, heads of school, businessmen and academics and individuals from other walks of life.

Volker Lenhart, whose chosen focus was the analysis of traditional conflicts through the lens of peace education, started by stating that peace education matters and highlighted the importance of peace education in the long-standing

1 19-20, October 2013, Schwetzingen, Germany

2 Wazir Ali is a Ph.D. student at the Corvinus University of Budapest.E-mail: wababer@gmail. com 
existence of countries like Israel-Palestine and Bosnia-Herzegovina. He then emphasised the depth of the pedagogical work that is required to put peace education into practice in conflict zones in different parts of the world. Prof. Lenhart concluded by making suggestions and by interacting with participants and taking questions regarding the effectiveness of peace education.

The next presentation made by Prof.em. Dr. Gavriel Salomon, was entitled 'How to Handle the Formidable Challenges facing Peace Education'. The speaker used different images to emphasise the different notions that exist about peace education in society. This approach is one of his strengths and the reason that his presentation was so lively. Prof Salomon employed very simple language and simple terminology to define his arguments. He talked about the importance of narratives in peace education in conflict zones, and focused on the 'other side of the conflict'. The main goal of peace education is to change the minds and hearts of people. Dr. Solomon discussed different challenges which peace education could (and has) faced, including the "not so collective efforts' that appear on both sides of a conflict. He maintained that, as members of society, our challenge is find ways to successfully deal with different challenges to the implementation of peace education, rather than ignoring them with the hope of those things will somehow work out. During the Q\&A session, participants asked different questions about the Israeli perspective on peace education and its implementation in on-going conflicts. Dr. Solomon agreed with different comments that noted that there is still a need to change the narratives that teachers and politicians use to achieve the different objectives of peace and peace education in conflict zones.

Later, Prof. Dr. Jonathan C. Taylor gave a presentation about 'The Role of Education in Post-Conflict Peace building and Development' based on the Liberian experience. Dr. Taylor talked about the United Nations Millennium Development Goals (MDGs) and employed them in an analysis of the Liberian case. He emphasized some of the experience he had gained from tutoring some students in Liberia during the conflict. He talked about the Liberian government and their policies in relation to achieving the UN MDGs with particular emphasis on the education sector and the challenge that Liberia has been facing in this regard.

In addition to this, Dr. Idris Hadi Salih from Northern Iraq also presented a case study about the role of education in peace building and the transformation of society. He used statistical data to illustrate how an increase in investment into private schools (particularly Turkish schools in Northern Iraq) has contributed to peace through promoting education. He concluded by remarking that education has played a significant role in fostering social stability and development in the Kurdistan region of Iraq. 
Prof. Dr. Havva Engin from the University of Heidelberg gave a presentation about 'Peace Education in Pluralistic Immigration Societies'. Dr. Engin employed an immigration perspective about education and focused on transcultural education systems. In Germany, according to the latest statistics, around $20 \%$ of the population have what is known as a 'migrant background' (and the percentage is much higher for the younger population). The speaker stated that the cultural and linguistic differentiation that exists in society is reflected most strongly in Germany's educational institutions - which will play a central role in preserving social peace in the future. She argued that the focal area of work for peace education should be addressing racism and discrimination at both an individual and societal level; further, she stressed the importance of acquiring intercultural competence (which is considered by UNESCO to be the core of peace education). She concluded that educational institutions in particular are required to act by employing appropriate pedagogical approaches to defend against discriminatory developments. Her research contributed (as one of the case studies) to the conference and highlighted the different challenges for peace education in which the role of teacher and parent are almost the same.

In a similar vein, Dr. Rene Ferguson from South Africa gave a presentation entitled 'Religion, Human Rights, Citizenship Studies as Contributors to Intercultural Understanding and Peace Education'. The presentation focused on reflections gained from teacher education community projects in Johannesburg, South Africa. It presented an analysis of the relevance of peace education, citizenship and human rights in the context of a community where conflicts were once at the highest level and society was divided. There was a great deal of interaction between the speaker and the participants at the talk. Later, Uli Jager, Director for Peace Education at the Berghof Foundation, gave a presentation about the experience of their organisation with peace education in schools in different conflict zones in different parts of world. He focused mainly on describing the situation of refugees in Jordan who have been victims of the on-going conflict in Syria.

One of the potential outcomes of the conference is the raising of awareness about peace education by promoting the holding of events at such a large scale. The other positive outcome is the fostering of the learning and understanding of peace education scholars. An important side effect of the conference for participants was the opportunity to network and socialize with each other, report on their experiences with peace education and to volunteer to share what they had learnt about peace education after listening to the speakers. The conference fostered interaction - not only between speakers and participants but also between the participants themselves. 